\title{
FACTORS AFFECTING THE FINANCIAL AND NON-FINANCIAL RATIOS ON GOING-CONCERN AUDIT OPINION
}

\author{
Icuk Rangga Bawono ${ }^{*}$ \\ Jenderal Soedirman University \\ 708, Prof. Dr. H.R. Boenyamin St., Banyumas \\ Indonesia 53122 \\ cukycutes@yahoo.com
}

\author{
Aan Kanivia ${ }^{2}$ \\ Catur Insan Cendekia University \\ 202, Kesambi St., Cirebon \\ Indonesia 45311 \\ aanwaroka@gmail.com
}

\author{
Oman Rusmana ${ }^{3}$ \\ Jenderal Soedirman University \\ 708, Prof. Dr. H.R. Boenyamin St., Banyumas \\ Indonesia 53122 \\ Oman.rusmana@unsoed.ac.id
}

\begin{abstract}
This study aims to determine the factors affecting the financial and non-financial ratios' ongoing concern audit opinion. Data were obtained from 31 property and real estate sub-sector companies listed on the Indonesia Stock Exchange (IDX) from 2014-2017, comprising 124 samples. The data collected were analyzed using the logistic regression analysis method. This result showed that the activity ratios, liquidity, audit quality, previous year's audit opinion, and shopping could affect the provision of a company's going concern audit opinion. Meanwhile, the ratio of profitability, solvency, and company size has a more negligible effect on the going-concern audit opinion.
\end{abstract}

Keywords: Non-financial Factors; Going Concern; Audit Opinion; Financial Ratio

\section{ABSTRAK}

Penelitian ini dilaksanakan dengan tujuan untuk mengetahui pengaruh rasio keuangan dan nonkeuangan terhadap opini audit going concern. Penelitian ini mengambil sampel 31 perusahaan subsektor property dan real estate yang terdaftar di Bursa Efek Indonesia (BEI) pada periode tahun 2014-2017 dengan total 124 sampel. Pengujian hipotesis menggunakan metode analisis regresi logistik. Penelitian ini menunjukkan bukti rasio aktivitas, likuiditas, kualitas audit, opini audit tahun sebelumnya, dan opinion shopping dapat memengaruhi pemberian opini audit going concern perusahaan. Sementara rasio profitabilitas, solvabilitas, dan ukuran perusahaan kurang memberikan efek terhadap pemberian opini audit going concern perusahaan.

Kata Kunci: $\quad$ Nonkeuangan; Going Concern; Opini Audit; Rasio Keuangan

JEL Classification: M41; M42

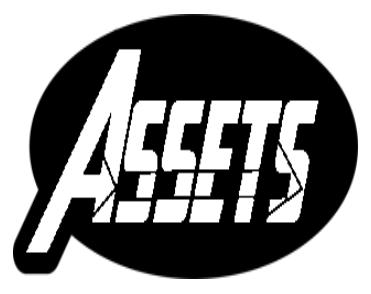

ASSETS

Jurnal Akuntansi dan Pendidikan

Vol. 10 No. 2

Page 87-100

Madiun, October 2021 p-ISSN: 2302-6251 e-ISSN: 2477-4995

Article History Submitted: July 14, 2020 Accepted: July 16, 2021 


\section{INTRODUCTION}

Indonesia is presently experiencing an increase in the need for housing due to the significant rise in population. According to Putra \& Sulasmiyati (2019), this need is seen from the yearly increase in apartments and houses, which led to advances in the property and real estate sub-sectors. Furthermore, the increase in property prices makes the real estate sub-sector a promising future investment. In 2017, this sub-sector experienced growth of IDR 746.8 trillion, approximately $12.10 \%$ from the previous year (Sandy, 2017). This sector contributed to the growth of the national economy. However, in 2017, IDX announced that $37.50 \%$ of companies are delisting due to their inability to comply with specific regulations, such as OAGC (Nurfitriyani, 2017). The auditor is mandated to acquire adequate audit evidence by the appropriate use of assumptions to maintain the sustainability of the issuer's business (Public Accountant Professional Standards of Auditing Standard Statement / SPAP PSA No.570, 2017). The financial community and the public expect the auditors to disclose problems that negatively affect the company. However, there are still cases where companies often fail even after a fair audit opinion is given (Lennox, 2000). Enron, Xerox, and Worldcom are clear examples that several auditors are deemed incompetent in providing transparent, accountable, relevant, and independent information (Rahmat, 2016).

This study utilized the signal theory to explain good and bad information capable of affecting the company's market perceptions on performance (Ross, 1977). The better the news is delivered, the more trust the market has in the company. Positive news significantly increases market trust. However, in an unfavorable economic situation, the going concern assessment of an entity is crucial for interested companies.

Furthermore, this study used the agency theory to analyze the company as an agent responsible for properly managing the resources to ensure it does not deviate from its goals (Jensen \& Meckling, 1976). The principals employ the agents to efficiently and effectively manage and utilize company-owned resources. In this case, they need insurance for their capital because sometimes the agent's actions are inconsistent with the owner's interests (Jensen \& Meckling, 1976). The provision of OAGC is a vital sign for a company's survival, which tends to affect principals, agents, and other interested parties. According to Muttaqin \& Sudarno (2012), OAGC is an adequate early warning on a company's failure and provides essential information to potential investors... Auditors' opinions are crucial because they evaluate the entity's ability to maintain business continuity (Indonesian Institute of Accountants, 2012).

Based on the research carried out on OAGC by Muttaqin \& Sudarno (2012), it was stated that auditors measure the company's survival using specific tools, namely financial and non-financial ratios, as an indicator of its ability. Consequently, financial ratio factors such as market value, activity, sales growth, profitability, liquidity, and leverage were further revealed. Meanwhile, the non-financial ratios examined in this study include client tenure auditors, opinion shopping, audit opinion results from last year, audit lag, the reputation of the Public Accounting Firm, and company size. In contrast to previous studies investigating manufacturing firms, this research analyzes companies in the property and real estate sub-sector. Furthermore, the seller growth ratio was excluded because the average company sales use a credit or due payment system. Additionally, it does not involve market value ratios because of its relation to profitability ratios.

The complete sample is available in the database. However, due to the phenomena that occurred in 2017, the span of the study period was from 2014 to 2017.

http://doi.org/10.25273/jap.v10i2.7024 
Meanwhile, the property and real estate sub-sector was selected because it is a longterm investment that guarantees continuous operation and sustainability. This study focuses on the following, (1) inconsistent results, (2) differences in the research subjects, (3) use of asset calculations as a proxy for financial ratios, and the addition of a grand theory. The phenomena in 2017 and the research gap are the two main reasons for reconducting the study on the property and real estate sub-sector.

\section{METHOD}

The population consists of 49 companies related to the property and real estate sub-sector listed on the Indonesia Stock Exchange (IDX) from 2014 to 2017. The purposive sampling technique was used to determine the samples. The criteria and number of final samples observed are shown in Table 1.

\section{Table 1. Sample Selection Technique}

\begin{tabular}{|c|c|c|}
\hline No. & Criteria & Total \\
\hline 1. & $\begin{array}{l}\text { The company in the property and real estate sub-sector listed on the IDX } \\
\text { from } 2014 \text { to } 2017\end{array}$ & 49 \\
\hline 2. & Delisting companies from the IDX from 2014 to 2017 & (3) \\
\hline 3. & $\begin{array}{l}\text { The company that published an audited annual report from December } \\
31 \text { for the period } 2014 \text { to } 2017\end{array}$ & (3) \\
\hline 4. & The company does not have a record of its annual report & 0 \\
\hline \multicolumn{2}{|r|}{ The samples that met the criteria } & 43 \\
\hline \multicolumn{2}{|c|}{ Outlier data } & $(12)$ \\
\hline \multicolumn{2}{|r|}{ The samples that met the criteria after the outlier } & 31 \\
\hline \multicolumn{2}{|r|}{ The total sample of research data (31 companies $x 4$ years) } & 124 \\
\hline
\end{tabular}

The data analysis adopted includes descriptive testing. Meanwhile, hypothesis testing was carried out using logistic regression analysis because the independent variable combines metric and nominal scales. Furthermore, the variable measurements are comprehensively described in Table 2 .

Table 2. Operationalization of Variables

\begin{tabular}{|c|c|c|}
\hline Variable & Measurement & Scale \\
\hline ROA $(X 1)$ & Profit after interest and tax / total assets & Ratio \\
\hline TATO (X2) & Net sales / total assets & Ratio \\
\hline DAR $(X 3)$ & Total debt / total assets & Ratio \\
\hline CR $(X 4)$ & Current assets / current liabilities & Ratio \\
\hline $\begin{array}{l}\text { Previous year's } \\
\text { audit opinion (X5) }\end{array}$ & $\begin{array}{l}\text { The values } 1 \text { and } 0 \text { are assigned to companies that } \\
\text { received and did not receive a going concern audit } \\
\text { opinion in the previous year, respectively. }\end{array}$ & Nominal \\
\hline Company Size (X6) & The natural logarithm of the total assets & Ratio \\
\hline Audit Quality (X7) & $\begin{array}{l}\text { The values } 1 \text { and } 0 \text { are assigned to companies that } \\
\text { use and do not use the services of The Big Four } \\
\text { Auditors. }\end{array}$ & Nominal \\
\hline $\begin{array}{l}\text { Shopping Opinion } \\
(\mathrm{X} 8)\end{array}$ & $\begin{array}{l}\text { The values } 1 \text { and } 0 \text { are assigned to companies that } \\
\text { changed and did not change their auditor, } \\
\text { respectively. }\end{array}$ & Nominal \\
\hline Going concern & A value of 1 is assigned to going concern opinion & Nominal \\
\hline
\end{tabular}




\begin{tabular}{ccc}
\hline Variable & \multicolumn{1}{c}{ Measurement } & Scale \\
\hline Audit Opinion (Y) & $\begin{array}{l}\text { (OAGC) while 0 is for non-going concern opinion } \\
\text { (NOAGC) }\end{array}$ & \\
\hline
\end{tabular}

Description: ROA: Return of Assets; TATO: Total Assets Turnover; DAR: Dept to Total Assets; CR: Current Ratio; OAGC: Going concern Audit Opinion

\section{RESULT AND DISCUSSION}

ROA is obtained using the profit after interest and tax formula divided by total assets proxies the profitability ratio (Kasmir, 2018). The lowest value is indicated by 0.06 owned by companies with the BKDP and MTSM codes in 2017. Meanwhile, the highest value of 0.20 is owned by those with the GWSA code. ROA with a negative value indicates that the company is experiencing business loss, which simply means that the paid-up capital has not generated profit. Meanwhile, a higher ROA value indicates that the company properly uses its assets to gain profitability. The average ROA shows that companies in the property and real estate sectors can earn $3.9 \%$ of their total assets. However, the standard deviation was more significant than the average ROA value. The deviation and variation in the profitability ratio realized from the company data from 2014 to 2017 are relatively high.

Table 3. Descriptive Statistics

\begin{tabular}{lccccc}
\hline & $N$ & Min & Max & Mean & Std. Deviation \\
\hline ROA & 124 & $-0,06$ & 0,20 & 0,0391 & 0,051 \\
TATO & 124 & 0,01 & 0,50 & 0,184 & 0,099 \\
DAR & 124 & 0,03 & 0,79 & 0,368 & 0,172 \\
CR & 124 & 0,01 & 19,07 & 2,798 & 2,991 \\
OATS & 124 & 0 & 1 & 0,24 & 0.430 \\
SIZE & 124 & 25,11 & 31,67 & 28,902 & 1,522 \\
KUALITAS & 124 & 0 & 1 & 0,19 & 0,397 \\
SHOP & 124 & 0 & 1 & 0,07 & 0,260 \\
OAGC & 124 & 0 & 1 & 0,19 & 0,397 \\
Valid N (listwise) & 124 & & & & \\
\hline
\end{tabular}

TATO is realized using the formula for net sales divided by total assets proxies for activity ratios (Kasmir, 2018). The lowest and highest TATO values are indicated by 0.01 and 0.50 owned by the companies with ELTY and BCIP codes in 2014 and 2015, respectively. The higher the TATO value, the more effectively it uses its assets to obtain sales and profits. The average TATO value is interpreted as companies' engaged in the property and real estate sector effectiveness of $18.4 \%$ and uses all assets to profit. Conversely, the standard deviation was less than the average TATO value. It simply means that the deviation and variation in the activities ratio realized from the companies' data from 2014 to 2017 are relatively low.

DAR is obtained using the total debt divided by total assets proxies' solvency (Kasmir, 2018). RBMS and PLIN own the lowest and highest DAR values of 0.03 and 0.79 in 2015 and 2017. The greater the DAR ratio, the more companies use loans to invest in assets useful for profits. The average DAR value shows that $36.8 \%$ of companies engaged in the property and real estate sector use loans to invest in assets to generate profit. Furthermore, the standard deviation was less than the average DAR value. The deviation and variation in the solvency ratio obtained from the company data from 2014 to 2017 are relatively low. 
$\mathrm{CR}$ is realized with the formula current assets divided by current liabilities proxies' liquidity (Kasmir, 2018). NIRO and MTSM own the lowest and highest CR values of 0.1 and 19.07 in 2014 and 2016. The greater the CR value, the more the availability of the current assets needed to cover short-term liabilities. The average CR shows that companies in the property and real estate sectors have current assets that are 2,789 times greater than the current liabilities. The standard deviation is greater than the average $C R$ value. It means that the deviation and variation in the liquidity ratios from the company data within 2014 to 2017 are relatively high.

OATS shows the OAGC opinion reported by the auditor in the previous year (Rianto, 2016; Suksesi \& Lastanti, 2016). The lowest value of OATS indicates a value of 0 successively obtained in the year of observation by the company with codes ASRI, BCIP, BEST, CTRA, DART, DILD, JRPT, KIJA, LPCK, MDLN, PLIN, PUDP, and TARA. Meanwhile, the maximum value of 1 was successively realized in the year of observation by BKDP and ELTY. Besides, companies with OAGC in the previous year are more likely to receive it in the current one. The total number of entities that successively received OAGC was less than those that did not receive it in the previous year. The average OATS shows that 24\% of companies within 2014 to 2017 received OAGC in the previous year. In addition, the standard deviations were more significant than the average OATS value. The OAGC deviation and variation in the previous year from 2014 to 2017 are relatively high.

The company size is based on the natural logarithm of the total assets. Nurpratiwi and Rahardjo (2014) reported that natural logarithms simplify the little numbers in the data. The lowest and highest values of 25.11 and 31.67 were owned by companies with the MTSM and LPKR codes in 2017, respectively. The company's SIZE is strongly affected by the total assets owned by the entity. Larger-sized companies tend to be effectively managing their resources as well as possess quality financial statements. The average SIZE value shows that companies engaged in the property and real estate sector from 2014 to 2017 had total assets of 28.902 billion. The standard deviation is less than the average SIZE value, which means that the deviation and variation from the company data are relatively low.

QUALITY is determined through the auditors' reputation proxies of the audit (Ginting \& Suryana, 2014; Rianto, 2016; Yuridiskasari \& Rahmatika, 2017). The lowest and highest values are 0 and 1, respectively. However, almost all companies used a non-big four Public Accounting Firm (KAP) consecutively in the observation year, except for CTRA, DART, GWSA, PLIN, and SMRA. The average QUALITY value shows that $19 \%$ of companies engaged in the property and real estate sector from 2014 to 2017 used the prominent four Public Accounting firms. The standard deviations were more significant than the average QUALITY value. It means that the deviation and variation in the audit quality from the company data are relatively high.

Djunaidi and Soepriyanto (2013) stated that the replacement of auditors is used to proximate operational shopping. The lowest and highest values are 0 , and 1 respectively. Unfortunately, almost all consecutively observed companies did not engage in operational shopping except those with the BIPP, BKDP, COWL, NIRO, RBMS, RODA, and SMDM codes in specific years. The average SHOP value shows that $7 \%$ of the companies engaged in the property and real estate sector from 2014 to 2017 changed the auditors used in the previous year. The standard deviation is greater than the average SHOP value, which means that the deviation and variation in opinion shopping from the company data are relatively high. 
OAGC projects give awards to companies. The lowest and highest values are 0 , and 1 respectively. Almost all companies did not receive OAGC in a row, except those with the BKDP and ELTY codes. Awarding OAGC to a company indicates that the firm can maintain its business activities in the long term. Therefore, it is not expected to be liquidated in the short term (Harjito, 2015). The average value shows that $19 \%$ of companies engaged in the property and real estate sector within 2014 to 2017 received OAGC on their financial statements. Furthermore, the standard deviation is greater than the average OAGC value, which means that the deviation and variation from the company data are relatively high.

Table 4 shows that Nagelkerke's R Square value is relatively 0.604 . Therefore, $60.4 \%$ comprises a combination of independent and dependent variables, while $39.6 \%$ is derived from other factors excluded in this research model. It shows that the simultaneous combination of the independent and dependent variables in this study consists of ROA, TATO, DAR, CR, OATS, SIZE, QUALITY, and SHOP to explain $60.4 \%$ of the variation that affects OAGC.

Table 4. The test result of Nagelkerke's R Square

\begin{tabular}{cccc}
\hline Step & -2 Log likelihood & Cox \& Snell R Square & Nagelkerke R Square \\
\hline 1 & $62,991^{\text {a }}$ & 0,378 & 0,604 \\
\hline
\end{tabular}

Table 5 shows that a predictive value of $66.7 \%$ was obtained using a regression model to get OAGC. Meanwhile, the predictive power of the ROA, TATO, DAR, CR, OATS, SIZE, QUALITY, and SHOP variables generally used in this study was 90.3. It shows that statistically, the predictive ability of the regression model is $90.3 \%$.

Table 5. Classification Matrix

\begin{tabular}{|c|c|c|c|c|c|}
\hline \multicolumn{3}{|c|}{ Observed } & \multicolumn{3}{|c|}{ Predicted } \\
\hline & & & \multicolumn{2}{|c|}{ OAGC } & \multirow[t]{2}{*}{ Percentage Correct } \\
\hline & & & 0 & 1 & \\
\hline \multirow[t]{3}{*}{ Step 1} & OAGC & 0 & 96 & 4 & 96,0 \\
\hline & & 1 & 8 & 16 & 66,7 \\
\hline & Overall 1 & & & & 90,3 \\
\hline
\end{tabular}

Table 6. Logistic Regression Test Results

\begin{tabular}{clcc}
\hline & & $B$ & Sig. \\
\hline \multirow{6}{*}{ Step $1^{\mathrm{a}}{ }^{\mathrm{a}}$} & ROA & 2,542 & 0,779 \\
& TATO & $-30,021$ & 0,002 \\
& DAR & 4,478 & 0,218 \\
& OATS & 0,431 & 0,010 \\
& SIZE & 1,600 & 0,024 \\
& KUALITAS & 0,318 & 0,346 \\
& SHOP & $-3,383$ & 0,045 \\
& Constant & 4,214 & 0,001 \\
\hline
\end{tabular}

\section{Profitability and Going Concern Audit Opinion (OAGC)}

Based on the logistic regression testing in Table 5, profitability does not affect OAGC. This result shows that profitability does not affect the provision of OAGC by auditors. Theoretically, the information quality conveyed by the company as an agent 
of the shareholder regarded as the principal needs to be guaranteed through an independent party, namely the auditor. The audited annual report summarizes the financial and non-financial information. Profitability is a good signal for owners that the company's performance within a particular period is high. It is not perceived as a determinant of issuing OAGC without analyzing other factors. It is because auditors do not regard profitability as the primary measure for its ability to maintain its survival.

Subsequently, profitability proxied by ROA reflects the company's generation of profit. However, in providing OAGC, and in addition to the profits earned, auditors pay attention to the company's ability to pay off its debts. Assuming the company has a more significant production, it is bound to require more funds. Besides, one of the funding structures obtained with a faster process is increased debt. The consideration of issuing OAGC by reviewing profitability is based on analyzing the source of funds used for production, ensuring company debt is authorized. These results are inconsistent with previous research, which stated that profitability significantly affects the OAGC issued to the company (Lie, Wardani, \& Pikir, 2016; Pasaribu, 2015; Saifudin \& Trisnawati, 2016; Wulandari, 2014).

It tends to occur because high profitability does not necessarily reflect a company's good performance. Besides, high profitability is accompanied by cost reduction, which in turn maximizes profit. In other words, high profitability leads to the reception of an OAGC (Saifudin \& Trisnawati, 2016). A profitability that has an insignificant effect on the OAGC provision, for example, in IDX listed companies from 2014 to 2017, does not accompany an increase in profit. It is evidenced by the company's average DAR value of $37.1 \%$, more significant than the industry's standard solvency ratio of $35 \%$.

\section{Activity and Going Concern Audit Opinion}

Based on logistic regression testing in Table 5, empirical evidence shows that the activity ratios affect OAGC inversely proportional. The greater the company's ongoing activities, the more it effectively manages its assets, attracting investors. Based on signal theory and financial ratios, auditors, in making disclosures, present the necessary information to achieve reporting objectives and serve various interested parties. The activity ratio needs to be considered because the company's running indicates the manager's ability related to its management. The more the investors, the more opportunities the company has in maintaining its businesses. The effective running of the company's operational activities indicates that the firm is appropriately managed, thereby reducing the possibility of getting an audit opinion with a going concern status (Zukriyah, 2012).

The cross-tabulation results proved that low TATO values from 0.01 to 0.24 were more likely to receive OAGC than those above 0.25 . The TATO descriptive analysis results show that the average value is smaller than the standard deviation. It indicates that an increase in earnings is offset by a decrease in the company's receivables. It also proves that companies in the property and real estate sub-sector receive OAGC because they have a low activity ratio.

These results are consistent with preliminary studies, which stated that the activity ratio significantly affects the provision of OAGC by auditors (Özcan, 2016; Rudkhani \& Jabbari, 2013). However, this is inconsistent with several other studies which stated that the company's activity ratio does not affect providing the audit opinion with a going concern status (Januarti \& Fitrianasari, 2008; Muttaqin \& 
Sudarno, 2012; Nurpratiwi \& Rahardjo, 2014; Putra \& Suryandari, 2010; Wulandari, 2014; Zukriyah, 2012).

\section{Solvency and Going Concern Audit Opinions}

Based on logistic regression testing in Table 5, empirical evidence shows that solvency has an insignificant effect on OAGC. It means that solvency does not affect auditors' issuance of OAGC to the company. This result is unable to explain the reason an increase in corporate debt tends to reduce agency problems. An increase in debt causes the company to save more cash for interest payments and loan principal, reducing the cash reserves. Auditors as third parties concerning signal theory are faced with assessing and auditing the company's financial statements. The audit either provides a positive or negative signal for the parties in the company. However, auditors are sometimes hesitant to disclose the company's OAGC in the audit report. This doubt is due to distorted personal feelings that are bound to accelerate the company's failure supposing the OAGC is disclosed. However, on the other hand, the auditor's OAGC disclosure is essential information to accelerate efforts to prevent problems that arise in the company, supposing it is appropriately handled. It raises the issue of the absence of a structured procedure for determining going concerns. Furthermore, the provision of this status is a difficult task. Therefore the activity ratio is not the leading benchmark in providing an audit opinion with a going concern.

The results of this study are in line with the previous research, which stated that solvency does not affect providing an audit opinion with a going concern status to the company (Ha et al., 2016; Ibrahim \& Raharja, 2014; Januarti \& Fitrianasari, 2008; Muhamadiyah, 2013; Muttaqin \& Sudarno, 2012; Putra \& Suryandari, 2010; Rafflesia, 2015; Sherlita \& Puspita, 2012; Suroto \& Kusuma, 2017; Wulandari, 2014). However, it does not support the statement that solvency affects the auditor in providing an audit opinion with a going concern status (Özcan, 2016; Rudkhani \& Jabbari, 2013; Alamsyah, 2017; Anita, 2017; Lie et al., 2016; Pasaribu, 2015; Saifudin \& Trisnawati, 2016).

These results indicate that in this sector, the company's capital is not dominated by long-term debt. It causes solvency to insignificantly affect the provisions of OAGC to companies in this sector. The mean DAR value of descriptive statistics shows that the OAGC and NOAGC groups are similar, namely $0.37(37 \%)$. It means that companies that receive an audit opinion with or without going concern status have high debt. However, companies in both OAGC and NOAGC groups have positive TATO scores. It shows that the OAGC and NOAGC groups can manage their assets correctly, therefore sales volume increases, and funds are obtained to pay off debts. Conversely, it was concluded that the solvency ratio is insignificant to providing an audit opinion with a going concern status.

\section{Liquidity and Going Concern Audit Opinions}

Based on logistic regression testing in Table 5, empirical evidence shows that liquidity significantly affects OAGC. A high liquidity ratio is in line with the auditors in terms of providing OAGC. According to the agency theory, one of the methods used to prevent conflicts of interest is to increase funding sources through debt. Business failures and cash flow problems that tend to befall the company in the future are earlier detected through the liquidity ratio (Sherlita \& Puspita, 2012). Poor liquidity reflects the company's inability to pay off short-term debt using the available assets. It leads to enormous credit and doubts regarding its survival, resulting in a higher chance for auditors to provide OAGC.

http://doi.org/10.25273/jap.v10i2.7024 
The liquidity ratio of 2.7980 possessed by the property and real estate sub-sector indicates that it is still more significant than the standard value, 2. However, 100 out of the 124 companies did not receive OAGC. The auditors provided OAGC with a view to low liquidity. These results are consistent with previous studies that stated that the liquidity ratio significantly affects OAGC (Salawu et al., 2017; Saifudin \& Trisnawati, 2016; Putra \& Suryandari, 2010; Januarti \& Fitrianasari, 2008; Boone et al., 2010). However, this is inconsistent with a previous study, which stated that the liquidity ratio has a significant effect on the provision of OAGC (Alamsyah, 2017; Anita, 2017; Gallizo \& Saladrigues, 2016; Lie et al., 2016; Muttaqin \& Sudarno, 2012; Özcan, 2016; Pasaribu, 2015; Rafflesia, 2015; Rudkhani \& Jabbari, 2013; Sherlita \& Puspita, 2012; Suksesi \& Lastanti, 2016; Zukriyah, 2012).

\section{Previous Year's and Going Concern Audit Opinion}

By the logistic regression testing in Table 5, OAGC is potentially awarded by the auditor, supposing the auditee has a track record of the previous year. In the previous year, companies that received OAGC were considered by the auditors in the subsequent one, thereby increasing the industry's potential to receive this variable. Besides, the signal theory explains the information distribution between owners, management, and outsiders interested in the company. It aims to reduce information asymmetry through products summarized in highly reliable financial statements. In ensuring confidence in the reliability of information produced by the company, it is necessary to seek the opinion of an independent party on the quality of the financial statement. Subsequently, the quality financial statement is expected to describe the actual condition of a company. This information is the previous year's audit opinion which affects the auditor in terms of providing OAGC.

Conversely, only 14 out of 30 companies in the property and real estate sectors received OAGC in the previous year. There is a tendency for auditors to provide OAGC after their track record in the previous year. It is in line with the research carried out by Mutchler (1985), which stated that the previous year's audit opinion was accurate compared to the other models.

These results are consistent with previous research, which stated that companies that received OAGC have a more significant potential to obtain another one in the subsequent year (Khaddafi, 2015; Muttaqin \& Sudarno, 2012; Suksesi \& Lastanti, 2016; Suroto \& Kusuma, 2017). It is due to the high probability of losing confidence in the public's eyes regarding its resilience. This loss of confidence leads to assumptions by investors and creditors, thereby inhibiting companies from bouncing back from the crisis (Suksesi \& Lastanti, 2016). Loss of public confidence is indicated by giving OAGC to a company. This labeling indeed results in a decrease in shares, difficulty obtaining loans, and loss of confidence from investors, creditors, and customers (Muttaqin \& Sudarno, 2012).

\section{Company Size and Going Concern Audit Opinion}

By the results of logistic regression testing in Table 5, the company size has an insignificant effect on OAGC. This result indicates that company size does not affect auditors in providing OAGC. It is described as a measure of the company's ability to manage its assets. The larger the company size, the less the tendency to go bankrupt (Muttaqin \& Sudarno, 2012). However, based on the agency theory, large companies tend to have higher agency costs than small ones (Jensen \& Meckling, 1976). It means that large companies are also at risk of bankruptcy. Therefore, the auditor did not rule 
out the process of issuing OAGC to these companies. According to Wulandari (2014), entities with large asset values do not necessarily mean that the company cannot obtain an audit opinion with a going concern paragraph. It is due to an increase in the obligations of the company. Conversely, adequately managed small companies with good performance and sustained for an extended period minimize the potential to receive an OAGC, as Saifudin and Trisnawati (2016) reported.

These results are consistent with previous research, which stated that company size has an insignificant effect on the provision of OAGC by auditors (Anita, 2017; Djunaidi \& Soepriyanto, 2013; Gallizo \& Saladrigues, 2016; Ginting \& Suryana, 2014; Januarti \& Fitrianasari, 2008; Putra \& Suryandari, 2010; Saifudin \& Trisnawati, 2016; Suksesi \& Lastanti, 2016; Suroto \& Kusuma, 2017; Zukriyah, 2012).

\section{Audit Quality and Going Concern Audit Opinions}

Considering the logistic regression results in Table 5, audit quality has a significant effect on OAGC. This result indicates that less qualified auditors tend to issue OAGC. In overcoming agency problems between the company as an agent and the owner as of the principal, the independent auditor as a third party is the guarantor of the industry's responsibilities in financial statements. An audited financial report is a form of assurance issued to the owner by an independent auditor. This form of guarantee is a signal to the owner to ensure that the information provided by the company is by reality. Therefore, audit quality is essential in assuring company owners.

It is consistent with the study carried out by Minerva et al. (2020), which stated that the audit process carried out by qualified auditor is beterr able to determine misstatements or fraud. Furthermore, qualified auditors can detect and reveal earnings management indications in the company's financial statements. The audited financial statements' lead to an increase in trust and tend to be used by parties interested in the information provided (Jensen \& Meckling, 1976). Regarding the signal theory, its practice in the field shows that companies habit replacing non-Big four public accounting firms (KAP) after receiving OAGC. Consequently, 3 out of the 24 companies that received OAGC used the big four KAP. It is because OAGC is an opinion that the company is unwilling to disclose to other external parties. It empirically supports previous research, which stated that audit quality significantly affects OAGC (Khaddafi 2015, Habib, 2013; Yuridiskasari \& Rahmatika, 2017; Ginting \& Suryana, 2014; Harjito, 2015; Ryu \& Roh, 2007).

\section{Opinion Shopping and Going Concern Audit Opinions}

Based on the logistic regression results in Table 5, opinion shopping has a significant effect on OAGC. It shows that the more the companies carry out opinion shopping actions, the more the OAGC is issued. Conversely, assuming these companies fail to engage in this type of shopping, they are bound to receive non-going concern audit opinions. It is because the company seeks auditors that support management's accounting treatment policies to achieve set goals. It follows the agency theory, which states that the company managers usually report good performance. The principals search for agents that tend to support the realization of the company's goals. The company adopts the change method to avoid receiving OAGC from the auditors. Unfortunately, the OAGC is the wrong signal for the owner. Therefore the owner employs an agent as the principal to maintain the excellent image of the company's performance. In the case of the property and real estate sector, the average company engaged in opinion shopping is 0.07 , which is relatively 0 . It indicates that most 
companies do not change auditors. Hence this is in line with the average number of companies that receive OAGC is 0.19 , meaning that most do not receive this variable.

These results empirically prove that opinion shopping significantly affects the OAGC (Lennox, 2000; Muttaqin \& Sudarno, 2012). The property and real estate subsector companies used as the sample show managers trying to make their audit report look good because it attracts investors.

\section{CONCLUSION}

The logistic regression analysis concluded that profitability, solvency, and company size did not affect OAGC. Meanwhile, the ratio of activity, liquidity, previous year's audit opinion, audit quality, and Opinion shopping affect OAGC.

The theoretical, practical, and empirical implications obtained are the activity ratio, liquidity, audit quality, previous year's audit opinion, and opinion shopping affect the company sustainability. Meanwhile, profitability, solvency, and company size do not affect the sustainability of a company. Practically, companies and auditors presume that the activity ratio, liquidity, audit quality, previous year's audit opinion, and opinion shopping are the central values highlighted to determine a company's sustainability. Besides, profitability, solvency, and company size are supporting data to assess a company's sustainability. Empirically, further studies tend to use audit quality variables, previous year's audit opinion, and opinion shopping because they are proven to affect OAGC.

This study is limited to the property and real estate sub-sector with an observation period of four years. Therefore, it cannot describe the entity's actual condition and the trend of long-term OAGC provision. Future studies are expected to use different years and industries to compare them with one another. They are also expected to use other variables such as audit lag, auditor client tenure, disclosure, etc.

\section{REFERENCES}

Alamsyah, S. (2017). Determinan Opini Audit Going Concern Pada Perusahaan Manufaktur di BEI Tahun 2013-2016. Balance Vocation Accounting Journal, 1(2), 2537.

Anita, W. F. (2017). Analisis Faktor-Faktor Yang Mempengaruhi Opini Audit Going Concern Pada Perusahaan Manufaktur Yang Terdaftar Di Bursa Efek Indonesia. JRKA, 3(2), 87-108.

Boone, J. P., Khurana, I. K., \& Raman, K. K. (2010). Do the Big 4 and the Second-tier firms provide audits of similar quality? Journal of Accounting and Public Policy, 29(4), 330-352. https:// doi.org/10.1016/j.jaccpubpol.2010.06.007

Djunaidi, A., \& Soepriyanto, G. (2013). Pengaruh Pergantian Auditor Dan Kualitas Audit Terhadap Opini Audit Going Concern: Studi Empiris Perusahaan Manufaktur di Bursa Efek Indonesia. Binus Business Review, 4(1), 514-530.

Gallizo, J. L., \& Saladrigues, R. (2016). An analysis of determinants of going concern audit opinion: Evidence from Spain stock exchange. Intangible Capital, 12(1), 1-16. https://doi.org/http://dx.doi.org/10.3926/ic.683

Ginting, S., \& Suryana, L. (2014). Analisis Faktor-Faktor yang Mempengaruhi Opini Audit Going Concern pada Perusahaan Manufaktur di Bursa Efek Indonesia. Jurnal Wira Ekonomi Mikroskil, 4(2), 111-120.

Ha, T. T., Nguyen, T. A. T., \& Nguyen, T. T. (2016). Factors Influencing The Auditor's Going -Concern Opinion Decision. The 10th International Days of Statistics and Economics, Prague, September 8-10, 1857-1870. 
Habib, A. (2013). A meta-analysis of the determinants of modified audit opinion decisions. Managerial Auditing Journal, 28(3), 184-216. https:// doi.org/10.1108/02686901311304349

Harjito, Y. (2015). Analisis kecenderungan Penerimaan Opini Audit Going Concern Pada Perusahaan Manufaktur. Jurnal Akuntansi, XIX (01), 31-49.

Ibrahim, S. P., \& Raharja. (2014). Pengaruh Audit Lag, Rasio Leverage, Rasio Arus Kas, Opini Audit Tahun Sebelumnya dan Financial Distress Terhadap Penerimaan Opini Going Concern. Diponegoro Journal of Accounting, 3(3), 1-11.

Indonesian Institute of Accountants. (2012). Standar Akuntansi Keuangan. Jakarta: IAI.

Januarti, I., \& Fitrianasari, E. (2008). Analisis rasio keuangan dan rasio non keuangan yang mempengaruhi auditor dalam memberikan opini going concern pada auditee (studi empiris pada perusahaan manufaktur yang terdaftar di BEJ tahun 2000-2005). Jurnal Maksi, UNDIP, 8(1), 43-58.

Jensen, M. C., \& Meckling, W. H. (1976). Theory of the Firm: Managerial Behavior, Agency Costs, and Ownership Structure. Journal of Financial Economics, 3(4), 305360. https://doi.org/10.1016/0304-405X(76)90026-X

Kasmir. (2018). Analisis Laporan Keuangan (1st ed.). Depok: Rajawali Press.

Khaddafi, M. (2015). Effect of Debt Default, Audit Quality and Acceptance of Audit Opinion Going Concern in Manufacturing Company in Indonesia Stock Exchange. International Journal of Academic Research in Accounting, Finance and Management Sciences, 5(1), 80-91. https:// doi.org/10.6007/IJARAFMS/v5-i1/1461

Lennox, C. S. (2000). Going-concern Opinions in Failing Companies: Auditor Dependence and Opinion Shopping. SSRN, 1-26. https:// doi.org/dx.doi.org/10.2139/ssrn.240468

Lie, C., Wardani, R. P., \& Pikir, T. W. (2016). Pengaruh Likuiditas, Solvabilitas, Profitabilitas, dan Rencana Manajemen terhadap Opini Audit Going Concern (Studi Empiris Perusahaan Manufaktur di BEI). Berkala Akuntansi Dan Keuangan Indonesia, 1(2), 84-105.

Minerva, L., Vivian, S.S., Stefani., Stefeny, W., \& Cindy A. L. (2020). Pengaruh Kualitas Audit, Debt Ratio, Ukuran Perusahaan dan Audit Lag terhadap Opini Audit Going Concern. Owner Riset dan Jurnal, 4(1), 1-15 https:// doi.org/10.33395/owner.v4i1.180

Muhamadiyah, F. (2013). Opini Audit Going Concern: Kajian Berdasarkan Model Prediksi Kebangkrutan, Pertumbuhan Perusahaan, Leverage Dan Reputasi Kantor Akuntan Publik. Media Riset Akuntansi, Auditing \& Informasi, 13(1), 79-111.

Mutchler, J. F. (1985). A Multivariate Analysis of the Auditor's Going-Concern Opinion Decision. Journal of Accounting Research, 23(2), 668. https:// doi.org/10.2307/2490832

Muttaqin, A. N., \& Sudarno. (2012). Analisis Pengaruh Rasio Keuangan Dan Faktor Non Keuangan Terhadap Penerimaan Opini Audit Going Concern (Studi Empiris Pada Perusahaan Manufaktur di BEI tahun 2008-2010). Diponegoro Journal of Accounting, 1(2), 1-13.

Nurfitriyani, A. (2017). BEI Persilakan Perusahaan yang Telah Delisting untuk Relisting. Retrieved December 18, 2019, from https:// www.wartaekonomi.co.id/read158881/bei-persilakan-perusahaan-yangtelah-delisting-untuk-relisting

Nurpratiwi, V., \& Rahardjo, S. N. (2014). Pengaruh Kualitas Audit, Opinion Shopping, Debt default, Pertumbuhan Perusahaan Dan Kondisi Keuangan Perusahaan Terhadap Penerimaan Opini Auditgoing Concern. Diponegoro Journal of Accounting, 3(3), 1-15. 
Özcan, A. (2016). Determining Factors Affecting Audit Opinion: Evidence from Turkey. International Journal of Accounting and Financial Reporting, 6(2), 45-62. https:// doi.org/10.5296/ijafr.v6i2.9775

Pasaribu, A. M. (2015). Pengaruh Kualitas Auditor, Likuiditas, Solvabilitas Dan Profitabilitas Terhadap Opini Audit Going Concern Pada Sub Sektor Makanan Dan Minuman Yang Terdaftar Di Bursa Efek Indonesia. JRAK, 6(2), 80-92.

Putra, R. H., \& Sulasmiyati, S. (2019). Pengaruh Faktor Eksternal dan Internal Terhadap Nilai Perusahaan (Studi pada Perusahaan Subsektor Properti dan Real Estate yang Terdaftar di Bursa Efek Indonesia Periode 2014-2017). Jurnal Administrasi Bisnis, 72(2), 21-29.

Putra, V. A., \& Suryandari, E. (2010). Analisis Rasio Keuangan Dan Faktor Non Keuangan Yang Mempengaruhi Auditor Dalam Memberikan Opini Audit Going Concern Pada Auditee. Jurnal Akuntansi \& Investasi, 11(1), 53-67.

Rafflesia, Y. (2015). Pengaruh Likuiditas, Leverage, Debt Default, Firm Growth, dan Disclosure Terhadap Opini Audit Going Concern Pada Perusahaan Property dan Real Estate yang Terdaftar di BEI Periode 2008-2013. Jurnal Akuntansi Unesa, 3(3), $1-27$.

Rahmat, Z. (2016). Pengaruh Debt Default, Disclosure, Audit Client Tenure, Dan Audit Lag Terhadap Penerimaan Opini Audit Going Concern Pada Perusahaan Real Estate Dan Property Di Bursa Efek Indonesia. JOM Fekon, 3(1), 1422-1435.

Rianto, K. (2016). Pengaruh Kualitas Auditor, Debt Default, Opinion Shopping, Opini Audit Tahun Sebelumnya Dan Reputasi Kap Terhadap Penerimaan Opini Audit Going Concern (Studi Empiris Pada Perusahaan Manufaktur di BEI). JOM FEKON, 3(1), 264-278.

Ross, S. A. (1977). The Determination of Financial Structure: The Incentive-Signaling Approach. The Bell Journal of Economics, 8(1), 23-40. https://doi.org/10.2307/3003485

Rudkhani, T. G. M., \& Jabbari, H. (2013). The effect of financial ratios on auditor opinion in the companies listed on TSE. European Online Journal of Natural and Social Sciences, 2(3), 1363-1373.

Ryu, T. G., \& Roh, C.-Y. (2007). The Auditor's Going-Concern Opinion Decision The Auditor's Going-Concern Opinion Decision. International Journal of Business and Economics, 6(2), 89-101.

Saifudin, A., \& Trisnawati, R. (2016). Pengaruh Ukuran Perusahaan, Profitabilitras, Likuiditas, Solvabilitas dan Pertumbuhan Perusahaan Terhadap Opini Audit Going Concern (Studi Empiris pada Perusahaan Manufaktur yang Terdapat di Bursa Efek Indonesia Tahun. Seminar Nasional Dan The 3rd Call for Syariah Paper, Syariah Paper Accounting FEB UMS, 589-601.

Sandy, K. F. (2017). BI: Sektor Properti Dorong Perekonomian Nasional. Retrieved June 20, 2019, from https://ekbis.sindonews.com/berita/1233551/179/bi-sektorproperti-dorong-perekonomian-nasional

Sherlita, E., \& Puspita, E. T. (2012). The Effect of Financial Ratios, Prior Audit Opinion, and Growth on the Auditors ' Going Concern Opinion. PROCEEDING The 13th Malaysia Indonesia Conference on Economics, Management and Accounting (MIICEMA) 2012, 148-160.

Suksesi, G. W., \& Lastanti, H. S. (2016). Pengaruh Opini Audit Tahun Sebelumnya, Reputasi Auditor, Ukuran Perusahaan, Profitabilitas, Likuiditas, Dan Solvabilitasterhadap Pemberian Opini Audit Going Concern. Seminar Nasional Cendekiawan 2016, 1-15. 
Suroto, L. R., \& Kusuma, H. (2017). Drivers of going concern audit opinions: empirical evidence from Indonesia. HOLISTICA, 8(2), 79-90. https:// doi.org/10.1515/hjbpa-2017-0015

Wulandari, S. (2014). Analisis Faktor-Faktor Yang Mempengaruhi Auditor Dalam Memberikan Opini Audit Going Concern. E-Jurnal Akuntansi Universitas Udayana, 6(3), 531-558.

Yuridiskasari, S., \& Rahmatika, D. N. (2017). Determinan Penerimaan Opini Audit Going Concern Pada Perusahaan Sub Sektor Property Dan Real Estate di Indonesia. Jurnal Kajian Akuntansi, 1(1), 1-10.

Zukriyah, A. (2012). Pengaruh Reputasi Auditor, Tenure, Ukuran Perusahaan, Opinion Shopping, Pertumbuhan Perusahaan, Profitabilitas, Likuiditas, Aktivitas, Dan Leverage Terhadap Opini Going Concern (Studi Kasus Pada Industri Dasar yang Listing di BEI Tahun 2008-2010). Jurnal Kajian Pendidikan \& Akuntansi Indonesia, $I(3), 1-21$. 